\title{
THE EFFECT OF CLIMATE ON TREE-RING CHRONOLOGIES OF NATIVE AND NONNATIVE TREE SPECIES GROWING UNDER HOMOGENOUS SITE CONDITIONS
}

\author{
EDWARD FELIKSIK and SŁAWOMIR WILCZYŃSKI \\ University of Agriculture in Krakow, Department of Forest Protection and Forest Climatology, \\ Al. 29 Listopada 46, 31-425 Kraków, Poland
}

Received 17 November 2008

Accepted 21 May 2009

\begin{abstract}
Dendroclimatic studies were carried out in the experimental stands composed of many tree species situated in the Polish part of the Baltic sea-coast. Increment cores were taken from a 100years old trees of 2 native species: Norway spruce (Picea abies (L.) Karst.), and Scots pine (Pinus sylvestris L.) and 3 nonnative species: Douglas fir (Pseudotsuga menziesii (Mirb.) Franco), Sitka spruce (Picea sitchensis (Bong.) Carr.) and Silver fir (Abies alba Mill.). Thirty trees of each species were cored. The relationships between the diameter increment and the thermal and pluvial conditions during the period from 1925 to 2005 were analyzed on the basis of standardized tree-ring chronologies and climatic data. It was found that precipitation and temperature of the growing season and months preceding that season affected the annual diameter increment of all investigated tree species. The current year winter and early spring temperatures as well as February and August precipitation had a similar effect on the variation of diameter increment of trees. On the other hand thermal and pluvial conditions of the current year June differentiated the increment rhythm of individual species. A very strong negative effect on diameter growth of trees was observed in the case of winter and early spring frosts. Norway spruce turned out to be a species most resistant to low temperatures. The investigated tree species, especially Norway spruce, was susceptible to water deficiency in the soil during spring and summer. In the case of Scots pine a high precipitation in June stimulated its growth. The diameter increments of Douglas fir, Sitka spruce, Scots pine, and Silver fir were more strongly connected with air temperature than with precipitation. So called all-species chronology of tree-ring width, constructed during this study, permitted to verify the factors having a similar effect on growth response of the investigated tree species. It reflected the mutual characteristics of diameter increments of trees of various species.
\end{abstract}

Keywords: dendrochronology, dendroclimatology, dendroecology, tree-ring chronology, native, nonnative, Pinus sylvestris, Picea abies, Abies alba, Pseudotsuga menziesii, Picea sitchensis.

\section{INTRODUCTION}

The diameter increment is an autogenous feature of trees, controlled by various external factors, including the climate. The development of chronologies of diameter increments makes possible wide comparative study of comparative studies concerning the ecological requirements of trees (Fritts, 1965). The tree populations studied during the provenance experiments, where the development and growth of individuals of various provenances or

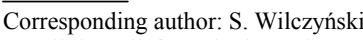
e-mail: janosik@n4u.krakow.pl

ISSN 1897-1695 (online), 1733-8387 (print) @ 2009 GADAM Centre, Institute of Physics, Silesian University of Technology.

All rights reserved. different species occurs under similar site conditions, are especially useful for this type of investigations. In dendroclimatic investigations, searching for climate-tree growth relationships, the choice of trees of proper age is also important. Such conditions were fulfilled by trees growing in experimental stands established by Cieślar and Schwappach in central Europe at the end of the $19^{\text {th }}$ century (Białobok and Chylarecki, 1965; Chylarecki, 1976). In Poland, the experimental area situated in the middle part of the Baltic sea-coast is especially interesting in this respect. This stand is composed from native coniferous tree species, as well as those nonnatives $(P$. menziesii, $P$. sitchensis) introduced from North America. 
The purpose of this study was to determine the susceptibility of native as well as nonnative tree species to selected elements of the Baltic sea-coast climate. We were searching for relationships occurring between the tree-ring width and the air temperature and precipitation. It is known that tree-ring growth of trees growing in a given area reflects the prevalent meteorological conditions in individual years. On the basis of this knowledge it is possible to determine the degree of adaptation of the investigated tree species to the climate, and to forecast their growth behavior in future. This in turn is especially important in the presence of observed and forecasted climatic changes.

\section{MATERIALS AND METHODS}

The study was conducted in the over a 100-year old stand composed by tree species, located in the Sławno forest district on the Baltic sea coast in the Western Pomerania (Trampler et al., 1990; Woś, 1999). The air temperature and precipitation data come from the IMGW (Institute of Meteorology and Water Economy) meteorological station located in Koszalin (co-ordinates: $54^{\circ} 12^{\prime}$, $16^{\circ} 10^{\prime} ; 33 \mathrm{~m}$ asl.). The research site is $40 \mathrm{~km}$ away from the meteorological station. This geographic and climatic region is characterized by a considerable number of moderately warm days with frequent precipitation. The number of days with hard or ground frost is relatively small. The growing season is rather long, i.e. 210 days on the average. The total annual precipitation is over $750 \mathrm{~mm}$, and in the warmer half-year it is $400 \mathrm{~mm}$ on the average. However, months with very low precipitation may occur in that area. The precipitation varies most during the growing season, and often trees are subjected to extreme pluvial conditions in this season so that such extreme precipitation events are important for tree growth (Fig. 1). The mean annual air temperature in this area is $7.8^{\circ} \mathrm{C}$. The temperature of the warmest month (July) is $16.9^{\circ} \mathrm{C}$, and of the coldest one (January) is $-1.1^{\circ} \mathrm{C}$. However, sometimes winter temperatures drop below $-10^{\circ} \mathrm{C}$, while during summer they often are above $30^{\circ} \mathrm{C}$. The mean temperature amplitude is relatively low amounting to about $18^{\circ} \mathrm{C}$. The nearness of the sea makes the thermal conditions mild. The mean monthly temperature varies most during winter.

There were 2 native tree species: Scots pine (PISY), and Norway spruce (PCAB), and 3 nonnative ones: Douglas-fir (PSME), Sitka spruce (PCSI) and Silver fir (ABAL). The species symbol is given in brackets (Grissino-Mayer, 2008). The stand was situated on a flat land, and the site represented a fresh mixed forest with acid brown soil. The individual species were growing in a group mixture with a moderate crown closure.

The 30 trees of Kraft's class I of each species were cored with the Pressler's increment borer, $1.3 \mathrm{~m}$ above the ground level. Tree-ring widths were measured on the cores thus obtaining tree-ring series. Ring dating accuracy was verified using the computer program COFECHA (Holmes, 1986). Next, on the basis of the tree-ring series the tree-ring width chronologies (WRC) were computed for trees of each species and population. This was followed by the standardization of the tree-ring
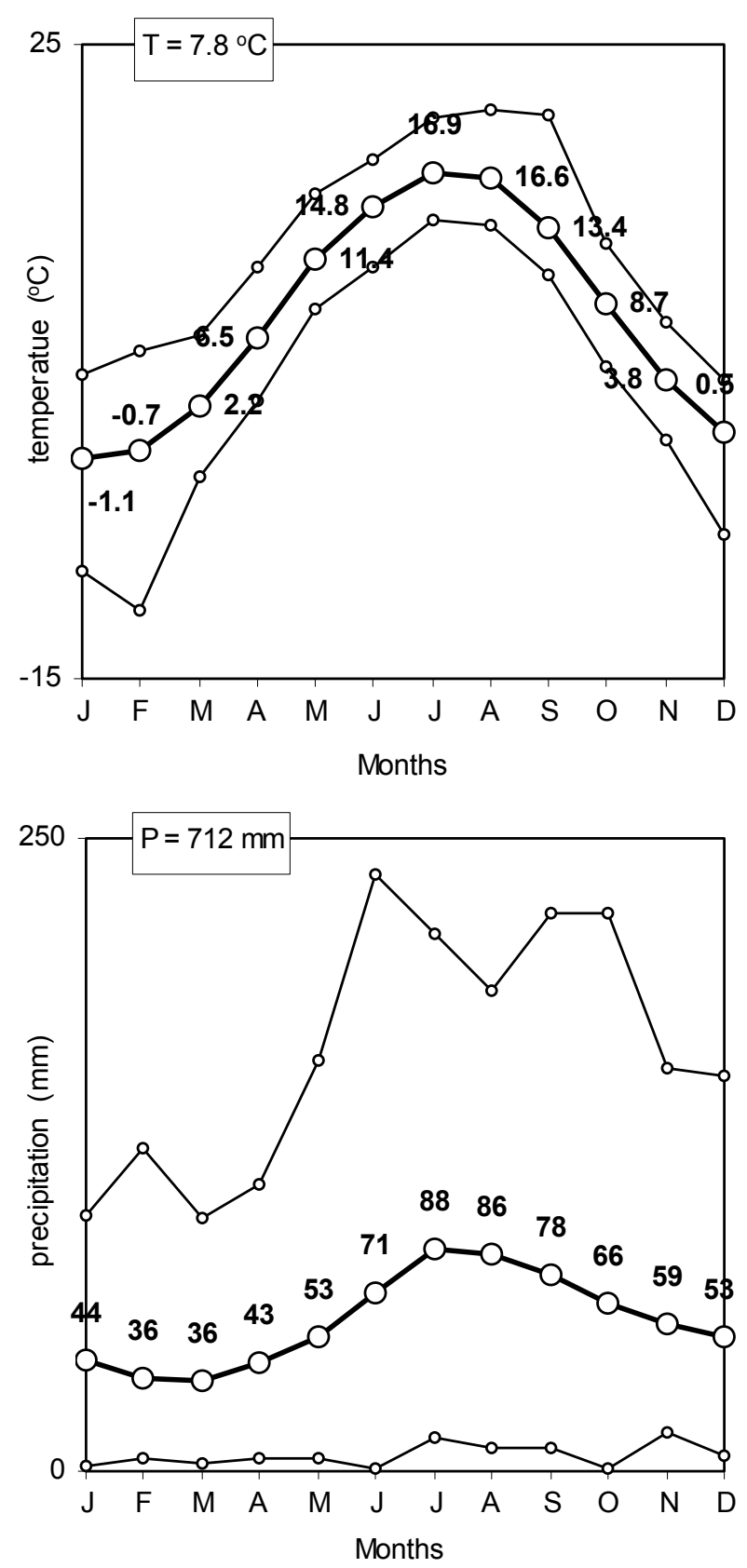

Fig. 1. The climatic diagram of the meteorological station in Koszalin for the 1923-2005 period. $T$ - mean annual air temperature, $P$ - mean total annual precipitation. Mean monthly temperature and total precipitation - line. The highest and lowest monthly values - thin lines (grey area).

series in order to remove trends and to strengthen a shortterm (annual) variation. On the basis of the standardized series the residual chronologies (CR) were developed. The computer program ARSTAN (Cook and Holmes, 1986) was used for this purpose.

In order to estimate the quality and representative character of chronologies, and strength of the climate signal in tree-rings the following indexes were computed: coefficient of correlation of the series with the standard chronology (rWz) (Holmes, 1986), mean sensitivity (C) (Fritts, 1976), EPS - Expressed Population Signal (Briffa, 1984; Wigley et al., 1984, Briffa and Jones 1990), and SNR (signal-to-noise ratio) (Briffa et al., 1987). The 
index EPS expresses the fraction of the general population chronology variance that is explained by the size $n$ sample chronology, while the index SNR informs about the ratio between the signal (short-term variation) and the noises (long-term variation) contained in chronologies of the investigated tree populations. The following formulae were used:

$$
\begin{aligned}
& E P S=n \cdot r_{\text {mean }} \cdot\left[1+(n-1) \cdot r_{\text {mean }}\right]^{-1} \\
& S N R=n \cdot r_{\text {mean }} \cdot\left(1-r_{\text {mean }}\right)^{-1}
\end{aligned}
$$

where: $r_{\text {mean }}-$ mean correlation coefficient between highfrequency standardized series, $n$ - number of series.

To determine the relationships between the tree-ring width and the air temperature and precipitation, correlation and multiple regression (response function) analyses (Fritts et al., 1971; Guiot, 1990) calculated by the program RESPO were used (Holmes and Lough, 1999).

It is known that the size of tree diameter increments is affected by weather conditions of the growing season and the previous months (Fritts, 1976). This is why the mean monthly values of air temperature and total precipitation were used as independent variables. They represented the period between the previous year May and September of the ring formation year. The increment indexes of residual chronologies (CR) were the dependent variables. The period from 1923 to 2005 was analyzed on the basis of data obtained from the nearby meteorological station of Koszalin.

In order to classify the tree-ring chronologies and to determine similarities between them, as well as to identify the factors controlling the variation of diameter increments, the following methods were used: the correlation and similarity (Huber, 1943; Eckstein and Bauch, 1969), cluster analyses, and the principal components analysis. For calculations the computer program STATISTICA 6.0 was used. In the Huber's method of similarity the agreement coefficient (Gleichläufigkeit) (GL\%) was computed according to the formula:

$$
G L=100 \cdot m \cdot(n-1)^{-1}[\%]
$$

where: $m$ - number of concordant (as to the direction) chronology sections, $n$ - length of the period under comparison in years.

This coefficient permits to estimate the agreement of the chronology direction in 2-year intervals, i.e. a shortterm variation.

Also the mean sensitivity (C) (Fritts, 1976) was computed for each species chronology. This is an index ex- pressing the degree of tree sensitivity (short-term variation) to environmental factors during a certain period of time. It was computed according to the following formula:

$C=\frac{\sum_{i=2}^{n}\left|c_{i}\right|}{n-1}$

where: $c_{i}=2 \cdot\left(x_{i}-x_{i-1}\right) \cdot\left(x_{i}+x_{i-1}\right)^{-1}, n-$ chronology length (years), $x$ - tree-ring width, $i$ - year.

\section{RESULTS}

Ring widths of 5 investigated tree species strongly varied from year to year. The species tree-ring width chronologies (WRC) shown in Fig. 2 graphically illustrate this variation. A high degree of agreement of all five chronologies may be observed. However, there were periods of time when the individual species chronologies were different from each other. This shows that on the one hand there were certain factors having a similar effect on growth rhythm of all tree species. On the other hand there existed factors which differentiated this rhythm. Their identification will be discussed below. A permanent decreasing trend in respect of the tree-ring width was observed during the analyzed period (1923-2005) lasting until the mid 1980s. Afterwards the wood increments became stable, and in some cases they even increased. This is clearly evident in standardized chronologies (CR). The increasing trend of diameter increments of European fir is marked with a trend line (Fig. 2).

During 1923-2005 Sitka spruce was characterized by the widest mean tree-ring $(3.09 \mathrm{~mm})$, while the mean tree-ring of Scots pine was the narrowest one $(2.11 \mathrm{~mm})$ (Table 1). Thus, certain differences in growth potential are evident among trees of the same age of individual species growing under the same site conditions. It turned out that foreign tree species as well as native European fir have attained the highest diameter increments during the last 80 years.

All tree species investigated during this study attained a relatively high mean coefficient of correlation between the tree series and their species chronologies $(\mathrm{rWz})$. In each case it exceeded the value of 0.6. This demonstrated that annual changes in tree-ring width of individual species were highly homogeneous. Thus, all species had a similar growth rhythm. Also values of the mean sensitivity (C) were relatively high. These values indicated a high

\begin{tabular}{|c|c|c|c|c|c|c|c|}
\hline \multirow{2}{*}{$\begin{array}{l}\text { Chronology } \\
\text { code }\end{array}$} & \multirow{2}{*}{$\begin{array}{l}\text { Mean ring width } \\
(\mathrm{mm})\end{array}$} & \multirow{2}{*}{ rWz } & $C$ & $A C$ & \multirow{2}{*}{$\begin{array}{c}\text { AC } \\
\text { WRC }\end{array}$} & \multirow{2}{*}{ EPS } & \multirow{2}{*}{ SNF } \\
\hline & & & \multicolumn{2}{|c|}{ CR } & & & \\
\hline$\overline{\mathrm{ABAL}}$ & 2.98 & 0.630 & 0.218 & -0.022 & 0.856 & 0.934 & 14.2 \\
\hline PCAB & 2.52 & 0.656 & 0.195 & -0.029 & 0.791 & 0.935 & 14.5 \\
\hline PISY & 2.11 & 0.681 & 0.232 & -0.011 & 0.822 & 0.946 & 17.4 \\
\hline PSME & 2.74 & 0.674 & 0.196 & -0.028 & 0.868 & 0.948 & 18.3 \\
\hline PCSI & 3.09 & 0.621 & 0.212 & -0.012 & 0.720 & 0.929 & 12.9 \\
\hline
\end{tabular}
sensitivity of trees to external factors, mainly to climatic

Table 1. Selected statistics of series and chronologies for the 1923-2005 period.

$r W z$ - mean correlation coefficient of the standardized series with the chronology, C - mean sensitivity, AC - autocorrelation 1-order, EPS - expressed population signal, SNR - signal-to-noise ratio, CR - residual chronology, WRC - tree-ring width chronology 

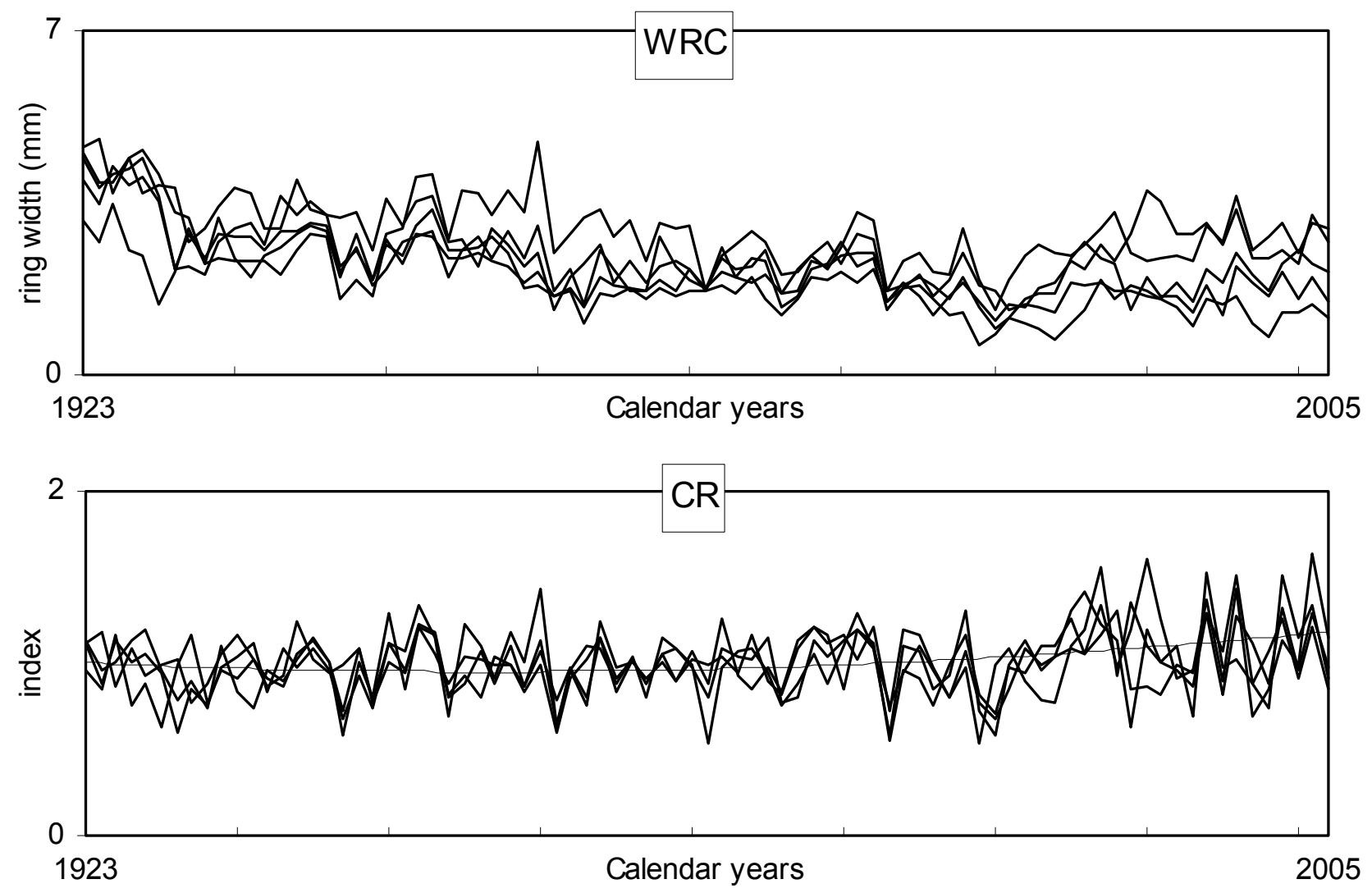

Fig. 2. Species tree-ring width chronologies (upper figure), and residual chronologies (lower figure).

conditions. The climate is the main factor controlling a short-term (annual) variation. The native Scots pine showed the highest sensitivity (0.232). Also Sitka spruce was quite sensitive, while the lowest sensitivity was found for the native Norway spruce (0.195) (Table 1).

The standardization of tree-ring series lowered values of the coefficient of autocorrelation of the chronologies $\mathrm{CR}$. They were very high in the case of the tree-ring width chronologies (WRC) (Table 1). This was confirmed by the progress of CR which was freed of the trend and of the most of the long-term fluctuations, characteristic for WRC (Fig. 2). Thus, the short-term (annual) variation was brought into prominence in standardized chronologies (CR). Therefore these chronologies make a good material for investigations concerning climate-tree growth relationships. The $\mathrm{CR}$ chronologies contain a strong climatic signal and are representative for hypothetical populations (Briffa and Jones, 1990). Also very high values of indexes EPS and SNR have confirmed this fact (Table 1).

The degree of similarity among chronologies CR was shown by the cluster analysis (Fig. 3). This may be considered to be a graphic representation of growth responses (annual changes in tree-ring width) of trees of a given population. The chronologies of trees from the genus Picea, i.e. Norway spruce and Sitka spruce, were the most similar to each other. Also the similarity between chronologies of Douglas-fir and European fir was relatively high. The chronology of Scots pine was least similar to chronologies of the remaining species (Fig. 3). It should be stressed, however, that the cluster analysis permits to determine only the degree of similarity between chronologies, i.e. the similarity between growth responses of tree populations.

In order to identify the factors controlling the similarities and differences between chronologies the principal component analysis (PCA) was used. Its results confirmed and widened the information obtained by the cluster analysis. The first factor accounted for $61.7 \%$ of the

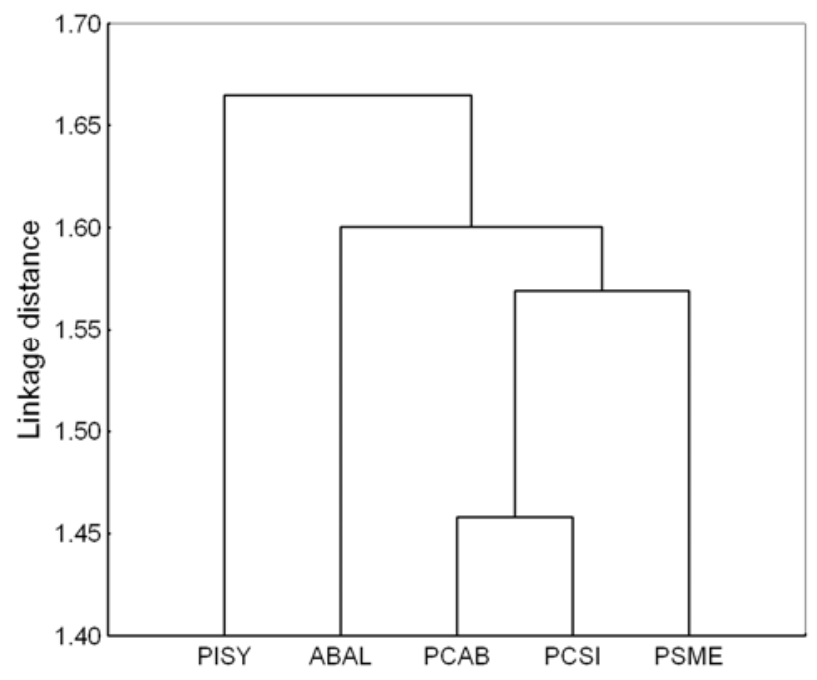

Fig. 3. Results of the hierarchical cluster analysis. The cluster tree (dendrogram) of the 4 species residual chronologies over the common period 1923-2005. The Ward's method and the Euclidean distance was used. 
total variance of the species CR, the second for $13.2 \%$, and the third one for $10.3 \%$. In total they explained $85 \%$ of the total chronology variance. Moreover, the first factor grouped all chronologies regardless of the species, while the second one differentiated the chronologies into three subgroups (Fig. 4). The first subgroup was formed by the chronologies of Norway spruce and Sitka spruce, the second - Silver fir and Douglas-fir, and the third Scots pine. The chronology grouping was very similar to that of the cluster analysis (Fig. 3). The chronologies of Norway spruce and Sitka spruce showed the highest positive correlation with the second factor, while the correlation of the Scots pine chronology with this factor was the lowest one. The third factor did not group chronologies into distinct subgroups.

In chronologies $\mathrm{CR}$ the short-term variation was brought into prominence. Therefore, the searching for the nature of the factors was carried out among the climatic parameters. Thus, the scores of the first three factors were correlated with monthly values of temperature and precipitation. The scores of the first factor were most significantly $(P<0.01)$ correlated with the mean temperature of winter and early spring months (January-April), the temperature of August, and the total precipitation of February. Their correlation with temperatures of February and March was the strongest one $(P<0.01)$ (Fig. 5). Therefore, these climatic parameters had a similar and essential effect on variation of diameter increments of all species. The scores of the second factor significantly correlated $(P<0.01)$ with total precipitation and temperature of the current year June (Fig. 5). Therefore, the thermal and pluvial conditions of early summer differentiated the growth behavior of the investigated tree species. The third factor did not show significant correlation with any of the climatic parameters. It may be supposed that its nature was non-climatic.

The results of PCA were confirmed by the analyses of the correlation and response functions (Fig. 6). These analyses showed that temperature of winter and early spring as well as precipitation in February had a similar positive effect on tree-ring width of all tree species under investigations. The total precipitation in June positively correlated with tree-ring width of both spruce species, and negatively with diameter increment of Scots pine. Silver fir had the greatest precipitation requirement in July. In the case of Douglas-fir no significant relationship between diameter growth and summer precipitation was found. High precipitation and low temperature during previous year summer and autumn had a positive effect on diameter increment of all tree species. This was most evident in both spruce species (Fig. 6).

High values of the coefficient of determination $\mathrm{R}^{2}$ of the response function showed that among various factors affecting the tree growth, the proportion of pluvial and thermal conditions was relatively high. In tree species investigated during this study, with the exception of Norway spruce, air temperature of winter and summer seasons was the main factor affecting diameter increment (Fig. 6). The role of air temperature in variation of treering width was most evident in Scots pine $\left(\mathrm{R}^{2}=39.8 \%\right)$ and foreign species, i.e. Douglas-fir $\left(\mathrm{R}^{2}=36.4 \%\right)$ and Sitka spruce $\left(\mathrm{R}^{2}=31.8 \%\right)$. In the case of Silver fir and
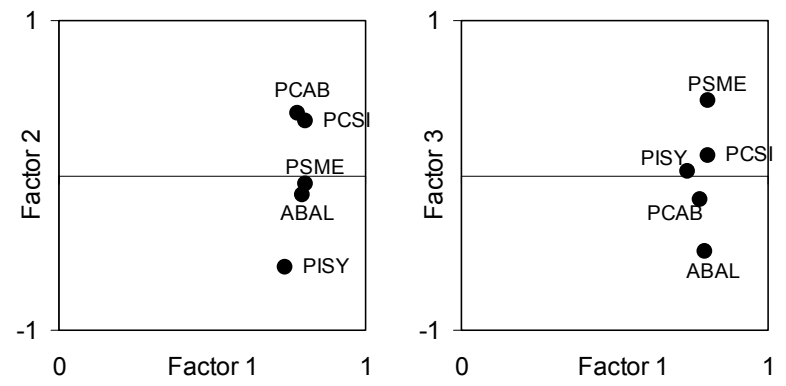

Fig. 4. Grouping of the species residual chronologies (CR) in relation to loads of the first 3 factors.

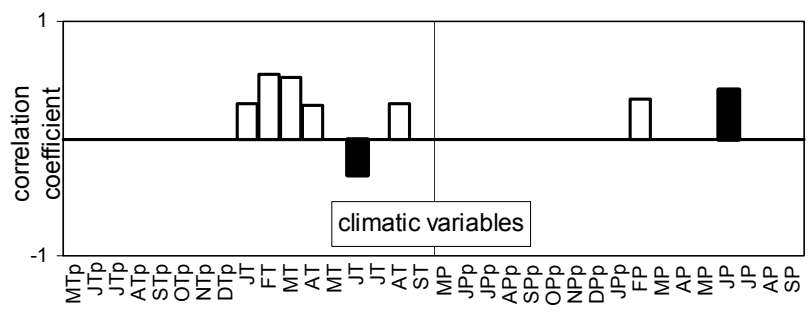

Fig. 5. Grouping of the species residual chronologies $(C R)$ in relation to loads of the first 3 factors.

Norway spruce this role was much lower $\left(\mathrm{R}^{2}=23.3 \%\right.$ and $18.3 \%$ respectively). The diameter increment of Norway spruce was more affected by precipitation $\left(\mathrm{R}^{2}=24.8 \%\right)$ of late winter and summer as well as of the previous year autumn. On the other hand the tree-ring width of Silver fir and Scots pine was most weakly connected with precipitation $\left(\mathrm{R}^{2}=13.5 \%\right.$ and $15.7 \%$ respectively) (Fig. 6).

A strong positive effect of late winter season temperature on diameter increment of trees was confirmed by significant similarity between the progress of five species chronologies and the curve of mean temperature of this season (Table 2). The weakest relationship with late winter temperature was found for Norway spruce. The agreement of its chronology with the curve of the mean February-March temperature was on the brink of significance.

In order to emphasize mutual characteristics of species chronologies the so called all-species chronology was constructed. It was the mean chronology of chronologies of the five tree species investigated. It turned out that it was strongly correlated with air temperature of the February-March period (Table 2). This fact was con-

Table 2. The agreement coefficient (GL) and correlation coefficient (r) between the residual chronologies (CR) and the mean February-March temperature for the 1923-2005 period.

\begin{tabular}{lll}
\hline Chronology code & GL $(\%)$ & $r$ \\
\hline ABAL & $72.3^{* *}$ & $0.447^{* *}$ \\
PSME & $74.7^{* *}$ & $0.646^{* *}$ \\
PCAB & $61.4^{*}$ & $0.385^{*}$ \\
PCSI & $77.1^{* *}$ & $0.550^{* *}$ \\
PISY & $80.7^{* *}$ & $0.614^{* *}$ \\
All-species chronology & $81.9^{* *}$ & $0.693^{* *}$ \\
\hline
\end{tabular}

Significant coefficients are marked by: ${ }^{*}-\mathrm{P}<0.05$ and ${ }^{* *}-\mathrm{P}<0.01$ 

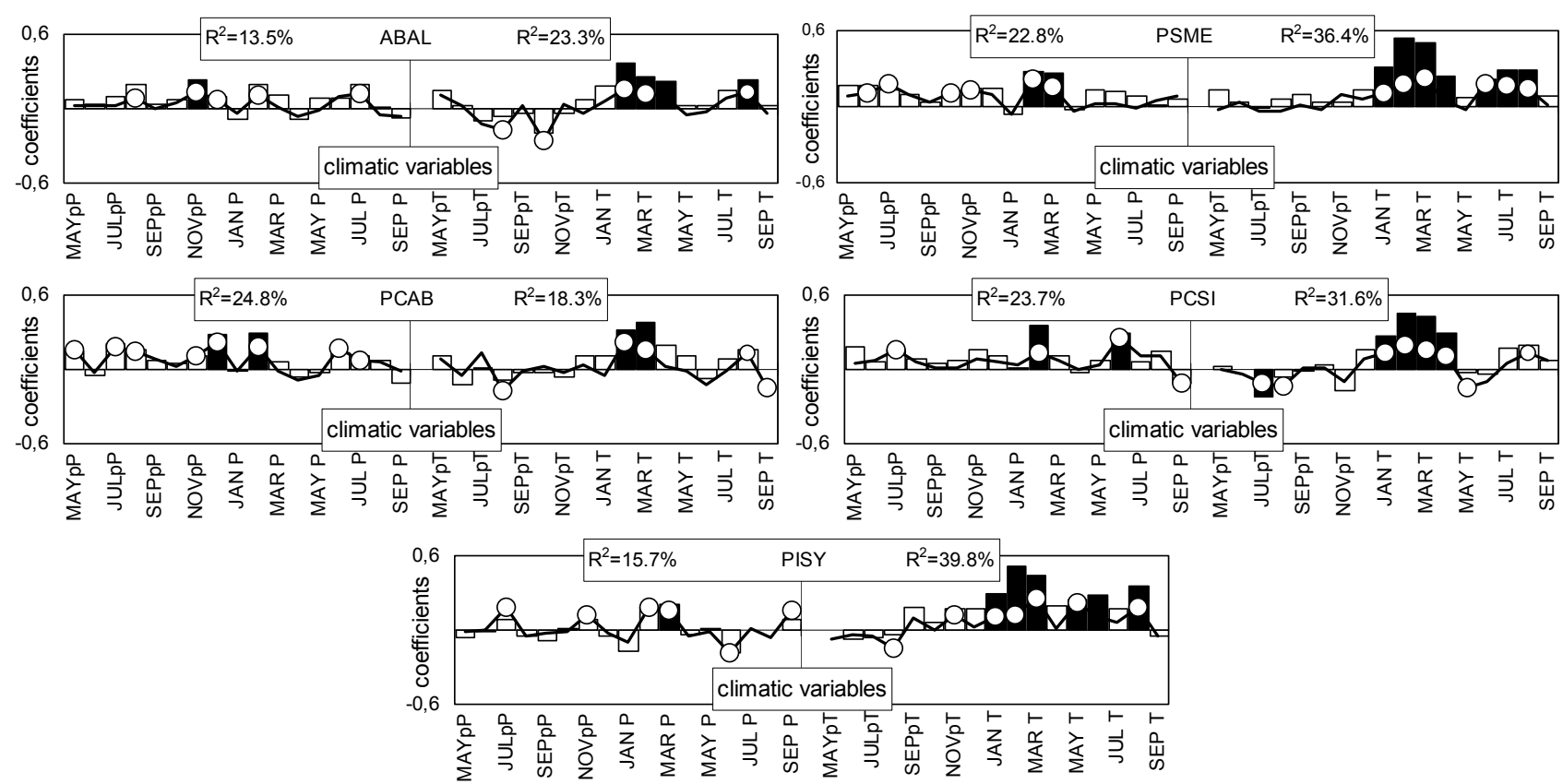

Fig. 6. Correlation (bars) and response (line) functions coefficients the residual chronologies and the mean monthly temperature and monthly total precipitation from the previous May (MAYp) to the current September (SEP) for the 1923-2005 period; $T$ - temperature, $P$ - precipitation. Significant $(\mathrm{P} \leq 0.05)$ correlation coefficients (black bars) and regression coefficients (white circles). Determination coefficients $\left(R^{2}\right)$ of the response function for precipitation and temperature are given in per cent.

firmed by its graphical comparison with the temperature curve of this period (Fig. 7). Once again this showed the dominant role of the late winter temperature played in growth processes of all five tree species.

To illustrate the changes of climatic elements in time, important for tree growth, the line of the mean temperature for the February-March period was drawn (Fig. 7). It turned out that a distinct increase of late winter temperature occurred during recent years. Probably this causes the earlier initiation of the growing season.

\section{DISCUSSION}

Due to the experimental character of the investigated stand tree growth was mainly affected by natural factors of the environment. The situation in managed stands is different because of intensive silvicultural treatments which disturb the natural environmental effects (Fritts, 1976; Schweingruber, 1983). Therefore, it may be supposed that information obtained during this study on climate (temperature and precipitation) - tree growth relationships is reliable.

The winter and early spring temperature was the main factor controlling the diameter increment of all investigated tree species in individual years. Long and frosty winters delayed activity of the cambium. The effect of February precipitation was of an indirect character. At the sea-coast the precipitation and temperature minima occur during the winter season. A lack of snow cover results in deep freezing of soil, which may lead to the occurrence of a "physiological drought" (Puchalski and Prusinkiewicz, 1990). It is especially dangerous to conifers physiologically active during winter. Besides, the snow cover is an important reservoir of water gradually released to the soil. This water is indispensable to trees in early spring when biochemical processes begin. However, spring in the investigated area is the season of scanty precipitation (Fig. 1) which not always meets the needs of trees.

The diameter increments of native Scots pine were most strongly dependent on air temperature. Apart from its susceptibility to low winter and early spring temperature it also required warmth during summer month. Under mild conditions of the sea-coast climate this is somewhat surprising. Such relationships were usually found in Scots pine growing in cool mountain regions (Wilczyński, 1999, 2003; Feliksik et al., 2002; Wilczyński and Skrzyszewski, 2002b), and at the northern border of its range (Briffa et. al., 1990; Lindholm et al., 1997; Tuovinen, 2005). In mountains, the terrain orography affects climate-tree growth relationships. For example trees growing in the precipitation shade of mountain ranges have greater precipitation requirements (Wilczyński and Skrzyszewski, 2002a). The temperature requirements for Scots pine populations growing in Polish lowlands are not of prime importance, and there, this species is more sensitive to precipitation scarcity during the growing season (Zielski, 1997; Wilczyński, 1999).

The climatic requirements of Silver fir growing on the Baltic sea-coast were not different from those found for this species during the dendroclimatic studies carried out so far. Warmth during winter and spring is important to growth of Silver fir occurring in lowland regions of Poland, but precipitation is also very important (Koprowski and Gławenda, 2007). In mountains, on the other hand, temperature is more important than precipitation (Feliksik, 1990). 


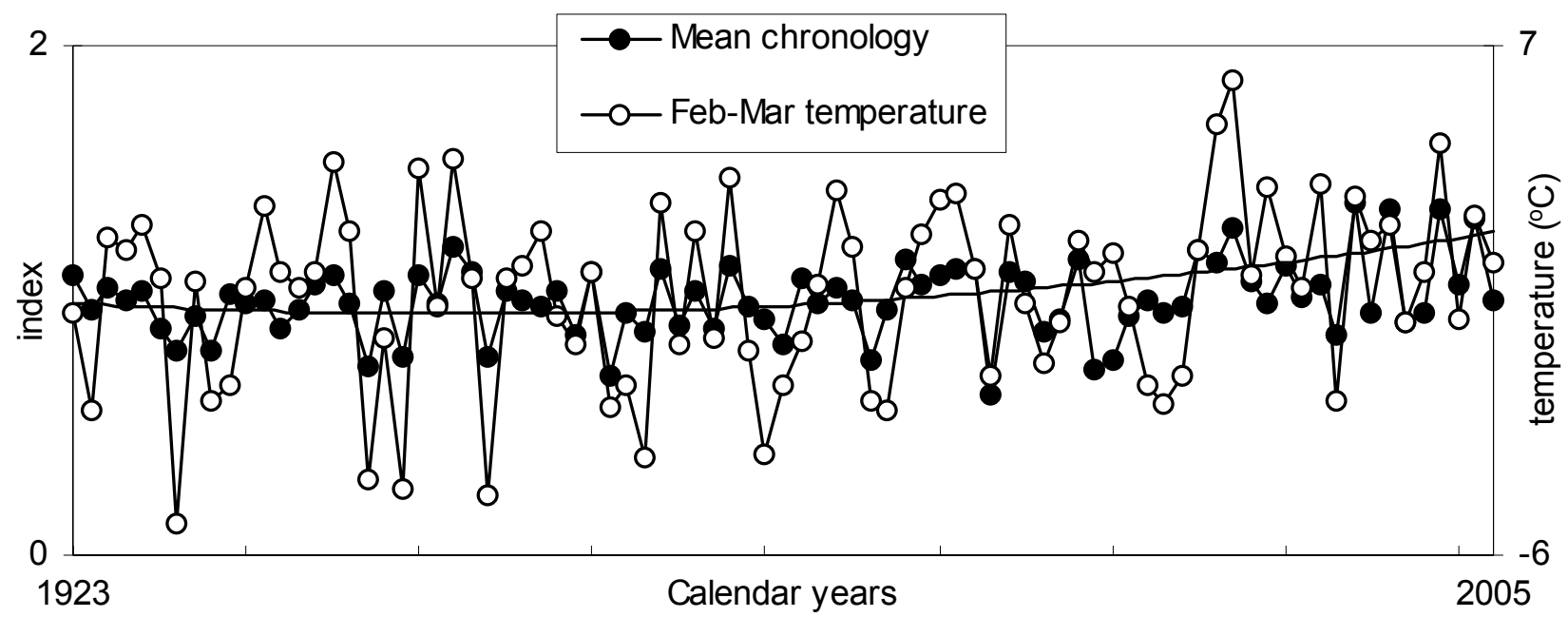

Fig. 7. The all-species chronology and the curve of the mean February-March temperature.

In the case of Norway spruce the pluvial conditions controlled diameter increment to a greater degree than the thermal ones. From among the investigated species it suffered most on account of soil moisture deficiency in spring and summer, but it was the most resistant species to low winter temperatures. Norway spruce populations of its Boreal-Baltic range are usually characterized by high precipitation and summer temperature requirements (Mäkinen et al., 2000; Zielski and Koprowski, 2001; Vitas, 2004; Koprowski and Zielski, 2006). Similar high moisture and thermal requirements were found for mountain populations of Norway spruce (Feliksik and Wilczyński, 2002, 2004b; Frank and Esper, 2005). This is mainly connected with high soil permeability and a flat root system of this tree species.

Sitka spruce naturally grows in North America under influence of oceanic climate characterized by high precipitation. This species requires much precipitation during the growing season and it is susceptible to very frosty winters (Flowells, 1965). Sitka spruce has been growing in Europe since the middle of the $19^{\text {th }}$ century. The best conditions for its growth are present under oceanic climate of British Isles. In continental Europe it suffers from winter frosts and summer droughts (Bellon et al., 1977; Feliksik and Wilczyński, 2008). On the Baltic sea-coast low temperatures of winter, spring, and summer turned out to be the factor most strongly limiting its diameter growth. Also water deficiency in spring and summer has a negative effect on Sitka spruce, similarly as in the case of Norway spruce. In both these species the effect of precipitation on variation of tree-ring width was very similar.

Douglas-fir in its natural range is characterized by great variability in respect of resistance to drought and frost. However, its climatic requirements are strongly connected with local site conditions (Flowells, 1965; Harlow et al., 1978). Under continental climate of North America, poor in precipitation during the growing season, its growth strongly depends on precipitation (Biondi, 2000; Zhang et. al 2000). In semiarid regions growth of Douglas-fir mainly depends on precipitation. But also an excessively high temperature which increases transpiration has a negative effect on its growth (Fritts, 1974; Cleveland, 1986; Biondi, 1997). Also European studies have confirmed the variability of Douglas-fir climatic requirements (Schober, 1963; Białobok and Mejnartowicz, 1970; Chylarecki, 1976; Feliksik and Wilczyński, 2003, 2004a,b; Wilczyński and Feliksik, 2007). The present study showed that on the Baltic sea-coast diameter increments of Douglas-fir were mainly controlled by thermal conditions of winter months, although they were important during the almost entire growing season. Besides Scots pine, Douglas-fir was the second species most sensitive to thermal conditions. Water delivered to soil from melting snow played a considerable role in formation of tree-rings of this tree species.

It was interesting to find that diameter increments of tree species under investigations depended to a certain degree on the previous year weather conditions. Low temperatures associated with high precipitation during summer and autumn of the previous year had a favorable effect on the next year tree growth. Probably such conditions favored the processes of nutrient storage and formation of high quality buds.

The dendroclimatic analyses presented in this paper clearly showed a very wide and variable time range of climate-tree growth relationships. This has confirmed the need of taking into account in studies of this type the climatic conditions of months previous to the growing season.

\section{CONCLUSIONS}

A high quality of trees of the species investigated during this study showed that their growth under conditions of a relatively mild climate of the Baltic sea-coast was normal and free of disturbances. The study results showed a high similarity between closely related Norway spruce and Sitka spruce in respect of the growth response. Such similarity was also observed between European fir and Douglas-fir in spite of the fact that these two species are native for two different continents. Scots pine, a na- 
tive tree for Poland, distinctly differed from other four species in respect of the wood increment rhythm influenced by local climate. Thus, the similarity in growth response is more connected with taxonomic (genetic) relations than with tree provenance. The introduced tree species become adapted to new, frequently different, climatic conditions without a greater problem presenting growth features of their local cousins.

The thermal factor controlling the diameter growth of trees was in the case of most species investigated during this study the dominant factor. It turned out that Scots pine, a species known to be resistant to low temperature, was the most susceptible to this climatic factor. Only in Norway spruce the pluvial factor determined growth more strongly than temperature. This factor also strongly affected growth of Sitka spruce. Probably this was connected with features of root systems of both spruce species, being usually flat and taking advantage of precipitation water of surface soil layers.

The dates of the beginning and end of the growing season are mainly determined by thermal conditions. It turned out that early spring air temperature is the most important factor for wood increment of trees. The treering width depends upon this temperature. During early spring and summer, when division of the cambium is intensive, also the pluvial factor is important for growth of trees. The positive effect of late winter precipitation indicated on the one hand a significant protective role of the snow cover, and on the other hand its function as a reservoir of water which gradually is released to soil in early spring.

It should be stressed that also the previous year thermal and pluvial conditions affect the cambium activity. They control the amount of nutrients stored as well as the quality of buds and the tree condition during the period of wintering, and in spring when growth begins.

Similarities and differences in sensitivity of trees to the climatic factor are disclosed in tree-ring width chronologies. The ring width may be considered as an external measure of tree sensitivity to the variable weather factor. If there are climate elements having a similar effect on increment responses of trees of various species, then this effect is revealed in a so called super-species chronology. This chronology shows mutual characteristics of various tree species resulting from their similar sensitivity to climatic elements.

A high quality of the investigated trees indicates that although a mild climate of the Baltic Sea controls the tree diameter increment, but it is not a destructive factor. Apart from native tree species such as Norway spruce, European fir or Scots pine also foreign species Sitka spruce and Douglas-fir may be successfully introduced to forests.

\section{REFERENCES}

Bellon S, Tumiłowicz J and Król S, 1977. Obce gatunki drzew w gospodarstwie leśnym (Nonnative tree species in forestry). Warszawa, Państwowe Wydawnictwo Rolnicze i Leśne: 267pp (in Polish).

Białobok S and Chylarecki H, 1965. Badania nad uprawa drzew obcego pochodzenia $w$ Polsce $w$ warunkach środowiska leśnego (Investi- gation on growing foreign trees in polish forests). Arboretum Kórnickie 10: 211-277 (in Polish).

Białobok S and Mejnartowicz L, 1970. Provenance differentiation among Douglas fir seedlings. Arboretum Kórnickie 15: 197-219.

Biondi F, 1997. Evolutionary and moving response functions in dendroclimatology. Dendrochronologia 15: 139-150.

Biondi F, 2000. Are Climate-Tree Growth Relationships Changing in North-Central Idaho, U.S.A.? Arctic, Antarctic, and Alpine Research 32(2):111-116, DOI 10.2307/1552442.

Briffa KR, 1984. Tree climate relationships and dendroclimatological reconstruction in the British Isles. Dissertation, University of East Anglia, Norwich, UK.

Briffa KR and Jones PD, 1990. Basic chronology statistics and assessment. In: Cook ER, Kairiukstis LA, eds., Methods of Dendrochronology. Applications in the Environmental Sciences. Dordrecht, Kluwer Academic Publishers: 137-152pp.

Briffa KR, Wigley TML and Jones PD, 1987. Standardization and the preparation of chronology: some contrasting approaches. In: Kairiukstis L, Bednarz Z, Feliksik E, eds., Methods of dendrochronology I. Proceedings of the Task Force Meeting on Methodology of Dendrochronology East/West Approaches, 2-6 June 1986, Krakow, Poland: 69-86pp.

Briffa KR, Bartholin TS, Eckstein D, Jones PD, Karlén W, Schweingruber FH and Zetterberg P, 1990. A 1,400-year tree-ring record of summer temperatures in Fennoscandia. Nature 346: 434-439, DOI $10.1038 / 346434 \mathrm{a} 0$.

Chylarecki H, 1976. Badania nad daglezja $w$ Polsce $w$ różnych warunkach ekologicznych (Researchs of Douglas fir in Poland in various ecological conditions). Arboretum Kórnickie 21: 15-124 (in Polish).

Cleveland MK, 1986. Climatic response of densitometric proporties in semiarid sites tree rings. Tree-Ring Bulletin 46: 13-29.

Cook ER and Holmes RL, 1986. Users manual for computer programs ARSTAN .In: Holmes RL, Adams RK and Fritts HC, eds., Treerings chronologies of Western North America: California, eastern Oregon and northern Great Basin. Tucson, University of Arizona, Chronology Series 6: 41-49.

Eckstein D and Bauch J, 1969. Beitrag zur Rationalisierung eines dendrochronologischen Verfahrens und zur Analyse seiner Aussagesicherheit. Forstwissenschaftliches Centralblatt 88(4): 230-250, DOI 10.1007/BF02741777.

Feliksik E, 1990. Badania dendroklimatologiczne dotyczace jodty (Abies alba Mill.) na obszarze Polski (Dendroclimatic research of Silver fir (Abies alba Mill.) in Poland) Rozprawy Habilitacyjne 151, Zeszyty Naukowe Akademii Rolniczej w Krakowie: 106pp (in Polish).

Feliksik E, Niedzielska B and Wilczyński S, 2002. Wrażliwość sosny reliktowej $z$ Tatr na warunki termiczno-pluwialne (The sensitivity of the relict pine from the Tatra Mountains to thermal and pluvial conditions). Sympozium Kraków-Zakopane, maj 2002, Tatrzański Park Narodowy oraz Polskie Towarzystwo Przyjaciół Nauk o Ziemi: 213-216pp (in Polish).

Feliksik E and Wilczyński S, 2002. Variability of tree-ring sizes of the Norway spruce (Picea abies (L.) Karst.) growing at different altitudes. Folia Forestalia Polonica Series A-Forestry 44: 87-96.

Feliksik E and Wilczyński S, 2003. Diversification of increment reactions of the Douglas fir (Pseudotsuga menziesii Franco) from the mountainous regions of southern Poland. Journal of Forest Science 49(12): 552-558.

Feliksik E and Wilczyński S, 2004a. Dendroclimatic regions of Douglas fir (Pseudotsuga menziesii (Mirb.) Franco) in western and northern Poland. Dendrobiology 52: 9-15.

Feliksik E and Wilczyński S, 2004b. The dendrochronological monitoring of the Western Beskid Mountains (southern Poland) on the basis of radial increments of Norway spruce (Picea abies (L.) Karst.). Electronic Journal Polish Agricultural University, series Forestry 7(2).

Feliksik E and Wilczyński S, 2008. Tree-ring chronology as a source of information on susceptibility of Sitka spruce to climatic conditions of Pomerania (northern Poland). Geochronometria 30: 79-82, DOI 10.2478/v10003-008-0002-0.

Flowells HA, 1965. Silvics of forest trees of Unites States. Washington Forest Service US Department of Agriculture, Agriculture Handbook 271 .

Frank D and Esper J, 2005. Characterization and climate response patterns of a high-elevation, multi-species tree-ring network in the 
European Alps. Dendrochronologia 22(2): 107-121, DOI 10.1016/j.dendro.2005.02.004.

Fritts HC, 1965. Tree-ring evidence for climatic changes in western North America. Monthly Weather Review 93(7): 421-443, DOI 10.1175/1520-0493(1965)093<0421:TREFCC $>2.3 . C O ; 2$.

Fritts HC, 1974. Relationships of rings widths in arid-site conifers to variations in monthly temperature and precipitation. Ecological Monograph 44: 411-440, DOI 10.2307/1942448.

Fritts HC, 1976. Tree-Rings and Climate. New York, London, San Francisco. Academic Press: 567pp.

Fritts HC, Blasing TJ, Hayden BP and Kutzbach JE, 1971. Multivariate techniques for specifying tree-growth and climate relationships and for reconstructing anomalies in paleoclimate. Journal of Applied Meteorology 10(5): 845-864, DOI 10.1175/15200450(1971)010<0845:MTFSTG>2.0.CO;2.

Grissino-Mayer HD, 2008. Species used in tree-ring research. http://web.utk.edu/ grissino/species.htm

Guiot J, 1990. Methods of calibration. In: Cook E and Kairiukstis L, eds., Methods of Dendrochronology. Dordrecht, Kluwer Academic Publishers: 165-178.

Harlow WM, Harrar ES and White FM, 1978. Textbook of Dendrology. Civering the Important Forest Trees of the United States and Canada. New York, McGraw-Hill Book Company: 134-136pp.

Holmes RL, 1986. Quality control of crossdating and measuring. Users manual for computer program COFECHA. In: Holmes RL, Adams RK and Fritts HC, eds., Tree-rings chronologies of Western North America: California, eastern Oregon and northern Great Basin. Tucson, University of Arizona. Chronology Series 6: 41-49.

Holmes RL and Lough JM, 1999. Users manual for program RESPO. Tucson, Laboratory of Tree-Ring Research, University of Arizona.

Huber B, 1943. Über die Sicherheit jahrringchronologischer Datierung (About the confidence of tree-ring dating). Holz als Roh- und Werkstoff 6(10-12): 263-268, DOI 10.1007/BF02603303.

Koprowski M and Zielski A, 2006. Dendrochronology of Norway spruce (Picea abies (L.) Karst.) from two range centres in lowland Poland. Trees DOI 10.1007/s00468-006-0051-9.

Koprowski M and Gławenda M, 2007. Dendrochronologiczna analiza przyrostów rocznych jodły pospolitej (Abies alba Mill.) na Pojezierzu Olsztyńskim (Nadleśnictwo Wichrowo) (Dendrochronological analysis of silver fir (Abies alba Mill.) annual increments in the Olsztynskie Lakeland (Wichrowo Forest District)). Sylwan 11: 35-40 (in Polish).

Lindholm M, Meriläinen J, Timonen M, Vanninen P and Eronen M, 1997. Effects of climate on the growth of Scots pine in the Saimaa Lake district, south-eastern Finland, in the southern part of the boreal forest belt. Dendrochronologia 15: 151-168.

Mäkinen H, Nöjd P and Mielikäinen K, 2000. Climatic signal annual growth variation of Norway spruce (Picea abies) along a transect from central Finland to the Arctic timberline. Canadian Journal Forest Research 30(5): 769-777, DOI 10.1139/cjfr-30-5-769.

Puchalski T and Prusinkiewicz Z, 1990. Ekologiczne podstawy siedliskoznawstwa leśnego (Ecological bases of forest sites). Warszawa, Państwowe Wydawnictwo Rolnicze i Leśne: 619pp (in Polish).

Schober R, 1963. Erfahrungen mit der Douglasie in Europa. Allgemeine Forstzeitschrift 18(30): 473-519.
Schweingruber FH, 1983. Der Jahrring. Standort, Methodik, Zeit und Klima in der Dendrochronologie (Tree-ring, site, methodology, time and climate in dendrochronology). Bern und Stuttgart, Verlag Paul Haupt: 235pp (in German).

Trampler T, Kliczkowska A, Dmyterko E and Sierpińska A, 1990. Regionalizacja przyrodniczo-leśna Polski na podstawach ekologiczno-fizjograficznych (The nature-forest regionalisation of Poland on the ecological and physiographical grounds). Warszawa, Państwowe Wydawnictwo Rolnicze i Leśne: 159pp (in Polish).

Tuovinen M, 2005. Response of tree-ring width and density of Pinus sylvestris to climate beyond the continuous northern forest line in Finland. Dendrochronologia 22(2): 83-91 DOI $10.1016 /$ j.dendro.2005.02.001.

Vitas A, 2004. Tree rings of Norway spruce (Picea abies (L.) Karsten) in Lithuania as drought indicators: dendroecological approach. Polish Journal of Ecology 2: 201-210.

Wigley TML, Briffa KR and Jones PD, 1984. On the average value of correlated time series with applications in dendroclimatology and hydrometeorology. Journal of Climate and Applied Meteorology 23(2): 201-213, DOI 10.1175/15200450(1984)023<0201:OTAVOC $>2.0$. CO $; 2$.

Wilczyński S, 1999. Dendroklimatologia sosny zwyczajnej (Pinus sylvestris L.) $z$ wybranych stanowisk $w$ Polsce (Dendroclimatology of Scots pine (Pinus sylvestris L.) from range sites in Poland). Dissertation, Katedra Klimatologii Leśnej, Akademia Rolnicza w Krakowie: $84 \mathrm{pp}$ (in Polish).

Wilczyński S and Skrzyszewski J, 2002a. The climatic signal in treerings of Scots pine (Pinus sylvestris L.) from foot-hills of the Sudetic Mountains (southern Poland). Forstwissenschaftiches Centralblatt 121(1): 15-24, DOI 10.1046/j.1439-0337.2002.01042.x.

Wilczyński S and Skrzyszewski J, 2002b. Dendrochronology of Scots pine (Pinus sylvestris L.) in the mountains of Poland. Journal of Forest Science 49(3): 95-103.

Wilczyński S, 2003. Modele klimat-przyrost radialny sosen z Tatr, Pienin i Ojcowa (The models of the climate - radial increments relationship for Scots pine from Tatra Mountains, Pieniny Mountains, and Ojców). Sylwan 12: 27-35 (in Polish).

Wilczyński S and Feliksik E, 2007. Local chronologies and regional diversity of dendrochronological signal of Douglas fir in Poland. Geochronometria 26: 69-80, DOI 10.2478/v10003-007-0008-z.

Woś A, 1999. Klimat Polski (The climate of Poland). Warszawa, Państwowe Wydawnictwo Naukowe: 301pp.

Zhang QB, Hebda RJ, Zhang QJ and Alfaro RI, 2000. Modeling treering growth responses to climatic variables using artificial neutral networks. Forest Science 46(2): 229-239.

Zielski A, 1997. Uwarunkowania środowiskowe przyrostów radialnych sosny zwyczajnej (Pinus sylvestris L.) w Polsce Północnej na podstawie wielowiekowej chronologii (Environmental conditions of radial growth of Scots pine (Pinus sylvestris L.) in northern part of Poland on the base of long-term chronology. Torun, Uniwersytet Mikołaja Kopernika: 127pp. (in Polish).

Zielski A. and Koprowski M. 2001. Dendrochronologiczna analiza przyrostów rocznych świerka pospolitego na Pojezierzu Olsztyńskim (Dendrochronological analysis of Norway spruce annual increments in the Olsztyńskie Lakeland). Sylwan 7: 65-73. 